\title{
Pengaruh Pendekatan Saintifik dengan Teknik Mind Mapping terhadap Keterampilan Proses Dasar dan Hasil Belajar Biologi Siswa Kelas XI SMA Negeri 2 Tanggul Jember The Effect Scientific Approach using Technique Mind Mapping on Basic Process Skills and Student Achivement of Biology Class XI SMA N 2 Tanggul Jember \\ Isnainiyah Raudhatin Kharimah, Suratno, Pujiastuti Pendidikan Biologi, Fakultas Keguruan dan Ilmu Pendidikan, Universitas Jember (UNEJ) Jln. Kalimantan 37, Jember 68121 \\ E-mail: suratno.fkip@unej.ac.id
}

\begin{abstract}
Abstrak
Tujuan dari penelitian ini yaitu untuk mengetahui perbedaan pendekatan saintifik dengan teknik mind mapping terhadap keterampilan proses dasar, dan untuk mengetahui pengaruh hasil belajar siswa. Penelitian ini merupakan jenis penelitian kuasi eksperimen yang menerapkan pendekatan saintifik dengan teknik mind mapping di kelas eksperimen dan menerapkan pembelajaran konvensional di kelas kontrol. Teknik analisis data terhadap keterampilan proses dasar dan hasil belajar afektif yaitu dengan Independent t-test, serta hasil belajar kognitif siswa yaitu dengan ANAKOVA. Dari hasil penelitian pada kelas eksperimen, perlakuan terdapat perbedaan terhadap keterampilan proses dasar siswa dengan nilai $(\mathrm{p})<0,05$. Rerata keterampilan proses dasar kelas eksperimen lebih tinggi yakni mengamati 3,8, memprediksi 2,4, mengukur 3,7, menyimpulkan 3,0 dan mengkomunikasikan 3,2 sedangkan rerata siswa kelas kontrol yakni mengamati 2,9, memprediksi 1,5, mengukur, 3,4, menyimpulkan 1,3 dan mengkomunikasikan 2,3. Penggunaan pendekatan saintifik dengan teknik mind mapping terhadap hasil belajar kognitif berpengaruh secara signifikan dengan nilai probabilitas lebih kecil dari 0,05 $(\mathrm{p}=0,000<0,05)$. Selisih rerata pre-test dengan post-test hasil belajar kognitif siswa sebesar 41,31 pada kelas eksperimen dan sebesar 31,89 pada kelas kontrol, sedangkan rerata hasil belajar afektif pada kelas eksperimen sebesar 99,64 dan hasil belajar afektif pada kelas kontrol sebesar 86,64. Hasil penelitian kuasi eksperimen menunjukkan bahwa pendekatan saintifik dengan teknik mind mapping berpengaruh secara signifikan terhadap keterampilan proses dasar dan hasil belajar siswa.
\end{abstract}

Kata Kunci: Pendekatan Saintifik, mind mapping, keterampilan proses dasar, hasil belajar

The purpose of this study is to determine the effect of scientific approach using mind mapping techniques on basic process skills, and to determine the effect of student learning outcomes. This study is a quasi-experimental research applying scientific approach using mind mapping technique in the experimental class and apply learning in class conventional control. Data analysis techniques to the basic process skills and affective learning outcomes is by Independent t-test, and the results of students' cognitive learning is by Anacova. From the results of research on the experimental class, there are differences in the treatment of the basic process skills of students with good grades $(p)<0.05$. Average basic process skills of the experimental class higher at 3.8 observes, predicts 2.4 , measuring $3.7,3.0$ and communicating conclude a mean of 3.2 while the control class 2.9 observes, predicts 1.5 , measure , 3.4, 1.3 and communicating concluded 2.3. The use of scientific approach to mind mapping techniques to cognitive learning outcomes significantly influence the probability value less than $0.05(\mathrm{p}=0.000<0.05)$. Difference in average pre-test to post-test cognitive achievement of students at 41.31 in the experimental class and the control class amounted to 31.89, while the average of affective learning outcomes in the experimental class at 99.64 and affective learning outcomes in the control class is 86.64 . Results of quasi-experimental research shows that the scientific approach to mind mapping technique significantly affect the basic process skills and student achivement.

Keywords: Scientific approach, mind mapping, basic process skills, student achivement

\section{Pendahuluan}

Pendidikan merupakan masalah penting yang tidak bisa dipisahkan dari kehidupan manusia. Kualitas pendidikan di Indonesia dinilai masih belum baik diukur dengan proses pembelajaran ataupun hasil belajar siswa. Selama ini kompetensi sebagai hasil dari pembelajaran yang sangat penting untuk diukur dan dimiliki siswa justru kurang diperhatikan [1].

Dalam rangka peningkatan kualitas belajar tersebut, pemerintah selalu melakukan perbaikan pada setiap kurikulum yang diterapkan, dan untuk saat ini kurikulum 
2013 menjadi pertimbangan bagi pemerintah. Menurut Hosnan [2] menjelaskan bahwa kegiatan pembelajaran dalam kurikulum 2013 diarahkan untuk memberdayakan semua potensi yang dimiliki siswa agar mereka dapat memiliki kompetensi yang diharapkan melalui upaya menumbuhkan serta mengembangkan sikap (attitude), pengetahuan (knowledge), dan keterampilan (skill).

Berdasarkan hasil wawancara yang telah dilakukan dengan guru matapelajaran biologi di SMA Negeri 2 Tanggul pada tanggal 29 Desember 2015, penelitian hasil belajar lebih menekankan mengukur aspek kognitif. Guru tidak terlalu mementingkan penilaian keterampilan proses sains siswa, keterampilan psikomotorik siswa, dan keterampilan dasar bekerja ilmiah atau berinquiry, sedangkan dalam kurikulum 2013 penilaian hasil belajar siswa mencakup empat kompetensi inti.

Dalam kurikulum 2013 pendekatan yang diterapkan adalah pendekatan saintifik (scientific approach), dalam kegiatan inti pembelajaran dengan menggunakan pendekatan ini siswa diharapkan mampu melaksanakan lima tahapan kegiatan. Lima tahap kegiatan dalam pembelajaran dengan pendekatan saintifik adalah kegiatan mengamati, menanya, mengumpulkan informasi, menalar dan mengkomunikasikan [3].

Sebagian besar siswa menganggap matapelajaran biologi sebagai matapelajaran hafalan dan sulit untuk dipahami[4]. Selain itu, banyak materi yang membutuhkan hafalan. Sementara pemahaman materi pelajaran tidak hanya sebatas menghafal materi saja namun bagaimana caranya agar memahami secara menyeluruh dan mampu menjelaskan serta membahasakan hubungan antara bagian satu dengan bagian yang lainnya secara teratur.

Salah satu usaha untuk membantu siswa dalam mencatat informasi dan dapat memudahkan siswa dalam mengingat kembali seluruh informasi yang telah diterima adalah dengan menggunakan teknik Mind mapping. Teknik Mind mapping merupakan salah satu bentuk pencatatan yang dapat mengakomodir berbagai masalah penyajian kembali (recalling) informasi-informasi yang telah dipelajari [5].

\section{Metode Penelitian}

Penelitian ini dilakukan di SMA Negeri 2 Tanggul. Jenis penelitian ini adalah quasi eksperimental dengan cara menerapkan pendekatan saintifik dengan teknik mind mapping pada kelas eksperimen dan model pembelajaran konvensional pada kelas kontrol. Populasi yang diambil dalam penelitian ini adalah siswa kelas XI, kemudian melakukan uji normalitas dan uji homogenitas untuk menentukan sampel dalam penelitian ini. Diperoleh kelas XI MIPA-1 sebagai kelas eksperimen dan XI MIPA-3 sebagai kelas kontrol.

Desain penelitian ini menggunakan rancangan eksperimen Pretest-Posttest Control Group Desain dimana untuk kelompok kontrol dan kelompok eksperimen menggunakan kelas yang homogen kondisi kelasnya. Adapun rancangan penelitian ditunjukkan pada Tabel 1. Metode pengumpulan data dalam penelitian ini antara lain dengan teknik observasi, dokumentasi, wawancara, dan tes. Metode observasi digunakan untuk mengetahui keterampilan proses dasar dan hasil belajar afektif siswa dalam proses pembelajaran. Teknik wawancara dilakukan untuk memperoleh informasi dari pihak yang diwawancarai yakni guru Biologi dan siswa. Tes yang digunakan dalam penelitian ini adalah pre-test yang dilakukan sebelum menerapkan pendekatan saintifik dengan teknik mind mapping dan post-test dilakukan setelah pembelajaran untuk mengukur hasil belajar kognitif.

Tabel 1. Rancangan penelitian kuasi eksperimen

\begin{tabular}{cccc}
\hline Kelompok & Pretest & Perlakuan & Postest \\
\hline $\mathrm{E}$ & $\mathrm{P}_{1}$ & $\mathrm{X}_{1}$ & $\mathrm{O}_{1}$ \\
\hline $\mathrm{K}$ & $\mathrm{P}_{2}$ & $\mathrm{X}_{2}$ & $\mathrm{O}_{2}$
\end{tabular}

\section{Keterangan :}

$\mathrm{E}=$ Kelas eksprimen

$\mathrm{K}=$ Kelas kontrol

$\mathrm{P}_{1}=$ Hasil pre-test pada kelas eksperimen sebelum diberi perlakuan

$\mathrm{P}_{2}=$ Hasil pre-test pada kelas kontrol sebelum diberi perlakuan

$\mathrm{X}_{1}=$ Perlakuan proses belajar mengajar menggunakan pendekatan Saintifik dengan teknik Mind mapping.

$\mathrm{X}_{2}=$ Perlakuan proses belajar mengajar menggunakan metode konvensional

$\mathrm{O}_{1}=$ Hasil post-test pada kelas eksperimen setelah diberi perlakuan

$\mathrm{O}_{2}=$ Hasil post-test pada kelas kontrol setelah diberikan perlakuan.

Analisis data yang digunakan untuk memperoleh data-data yang digunakan selama penelitian ini adalah dengan analisis Independent Sample T-test untuk mengetahui perbedaan pendekatan saintifik dengan teknik mind mapping terhadap keterampilan proses dasar dan hasil belajar afektif siswa serta analisis Kovarian (ANAKOVA) untuk menguji pengaruh pendekatan saintifik dengan teknik mind mapping terhadap hasil belajar kognitif siswa.

\section{Hasil Penelitian}

Berdasarkan hasil penelitian yang telah dilakukan diperoleh rerata keterampilan proses dasar siswa pada Tabel 2. Rerata nilai keterampilan proses dasar siswa

\begin{tabular}{lccccc}
\hline & Mengamati & Memprediksi & Mengukur & Menyimpulkan & $\begin{array}{l}\text { Mengkomuni } \\
\text { kasikan }\end{array}$ \\
\hline Kelas & & & & & \\
\hline $\begin{array}{l}\text { Eksperi } \\
\text { men }\end{array}$ & 3,8 & 2,4 & 3,7 & 3,0 & 3,2 \\
\hline Kontrol & 2,9 & 1,5 & 3,4 & 1,3 & 2,3 \\
\hline
\end{tabular}

Dari hasil rerata nilai keterampilan proses dasar pada tabel 2 menunjukkan bahwa indikator dalam keterampilan proses dasar di kelas eksperimen lebih besar daripada kelas kontrol yakni mengamati pada kelas eksperimen didapatkan rerata 3,8 sedangkan kelas kontrol 2,9 pada indikator memprediksi kelas eksperimen didapatkan 2,4 sedangkan pada kelas kontrol 1,5 pada indikator mengukur kelas 
ekperimen memiliki rata-rata 3,7 dan kelas kontrol 3,4 pada indikator menyimpulkan kelas ekperimen memiliki rata-rata 3,0 pada kelas kontrol sebesar 1,3 pada indikator mengkomunikasi kelas eksperimen memiliki rata-rata 3,2 sedangkan pada kelas kontrol sebesar 2,3. Selanjutnya dilakukan uji t. dari hasil uji $t$ dapat diketahui nilai probabilitas 0,000 atau $(p)<0,05$. dengan demikian terdapat perbedaan perlakuan pendekatan saintifik dengan teknik mind mapping terhadap keterampilan proses dasar siswa secara signifikan.

Untuk hasil belajar siswa diperoleh data hasil belajar afektif dan kognitif. Nilai afektif diukur berdasarkan observasi pada saat pembelajaran. Berikut rerata hasil belajar afektif siswa.

Tabel 3. selisih rerata hasil belajar afektif siswa

\begin{tabular}{lccccc}
\hline Kelas & $\mathrm{N}$ & $\begin{array}{c}\text { Pertemuan } \\
\text { pertama }\end{array}$ & Kriteria & $\begin{array}{c}\text { Pertemuan } \\
\text { kedua }\end{array}$ & Kriteria \\
\hline $\begin{array}{l}\text { Eksperi } \\
\text { men }\end{array}$ & 39 & 99,46 & $\begin{array}{c}\text { Sangat } \\
\text { baik }\end{array}$ & 99,82 & Sangat \\
baik & bangat \\
Kontrol & 38 & 85,92 & $\begin{array}{c}\text { Sangat } \\
\text { baik }\end{array}$ & $\begin{array}{c}\text { Sangat } \\
\text { baik }\end{array}$ \\
\hline
\end{tabular}

Berdasarkan tabel di atas dapat diketahui bahwa hasil belajar afektif siswa pada kelas eksperimen lebih besar daripada hasil belajar pada kelas kontrol. Pada pertemuan pertama rerata nilai afektif pada kelas eksperimen adalah 99,46 dan pada pertemuan kedua 99,82 sedangkan pada kelas kontrol pada pertemuan pertama didapatkan rerata 85,92 dan pada pertemuan kedua didapatkan rerata 87,36 . Selanjutnya dilakukan uji t. dari hasil uji $t$ diperoleh nilai probabilitas 0,000 atau $(\mathrm{p})<0,05$ maka terdapat perbedaan yang signifikan hasil belajar afektif antara kelas kontrol dan kelas eksperimen.

Nilai kognitif diukur berdasarkan nilai pre-test dan posttest. Berikut rerata hasil belajar kognitif siswa. Tabel 4. selisih rerata hasil belajar kognitif siswa

Tabel 4. selisih rerata hasil belajar kognitif siswa
\begin{tabular}{|c|c|c|c|c|}
\hline Kelas & $\mathrm{N}$ & $\begin{array}{c}\text { Rerata } \\
\text { Pretest } \pm \mathrm{SD}\end{array}$ & $\begin{array}{c}\text { Rerata } \\
\text { Posttest } \pm \text { SD }\end{array}$ & $\begin{array}{c}\text { Rerata } \\
\text { selisih }\end{array}$ \\
\hline Eksperimen & 39 & $39,97 \pm 8,7$ & $81,28 \pm 5,1$ & 41,31 \\
\hline Kontrol & 38 & $38,18 \pm 8,5$ & $70,07 \pm 4,5$ & 31,89 \\
\hline
\end{tabular}

Berdasarkan tabel diatas dapat diketahui bahwa selisih rerata nilai pre-tes dan pos-tes di kelas eksperimen lebih besar $(41,31)$ dibandingkan dengan kelas kontrol $(31,89)$. Selanjutnya dari hasil uji ANAKOVA diketahui nilai probabilitas 0,000 atau $(\mathrm{p})<0,05$ sehingga terdapat pengaruh perlakuan pendekatan saintifik dengan teknik mind mapping terhadap hasil belajar kognitif siswa secara signifikan.

\section{Pembahasan}

Pelaksanaan pembelajaran di kelas eksperimen merupakan pembelajaran menggunakan pendekatan saintifik dengan teknik mind mapping. Penelitian ini bertujuan untuk mengetahui keterampilan proses dasar siswa dan hasil belajar siswa. Terdapat lima indikator dalam keterampilan proses dasar siswa yaitu mengamati, memprediksi, mengukur, menyimpulkan dan mengkomunikasikan.

Pada keterampilan proses dasar siswa hasil analisis uji-t menunjukkan nilai signifikansi $0,000(<0,05)$ maka $\mathrm{H}_{0}$ ditolak dan $\mathrm{H}_{1}$ diterima dengan asumsi bahwa terdapat perbedaan signifikan terhadap keterampilan proses dasar siswa. Peningkatan skor keterampilan proses dasar siswa disebabkan penerapan pendekatan saintifik dengan teknik mind mapping ditandai dengan dalam pembelajaran siswa benar-benar mengamati dengan mencari jawaban informasi yang dibutuhkan, siswa cenderung lebih aktif untuk mencari informasi dan siswa juga berkolaborasi dalam memecahkan masalah yang dihadapi. Melalui pendekatan saintifik dengan anggota kelompok yang heterogen memungkinkan siswa untuk saling bertukar pikiran, bekerja sama dalam memecahkan masalah yang diharapkan siswa satu dengan lainnya dapat bekerjasama dalam memecahkan masalah dengan serangkaian keterampilan proses dasar. Dengan demikian pendekatan saintifik menjadi pendekatan pembelajaran yang dapat mengembangkan keterampilan proses dasar siswa karena dalam proses pembelajarannya guru menyajikan materi dalam bentuk pertanyaanpertanyaan. Pertanyaan tersebut akan merangsang siswa untuk mencari jawaban dengan serangkaian keterampilan proses karena selain para siswa mencoba menjawab pertanyaan-pertanyaan atau memecahkan masalah, siswa juga dapat termotivasi untuk menciptakan pertanyaan.

Pembelajaran pendekatan saintifik merupakan pembelajaran yang aktivitas pembelajarannya menggunakan pembelajaran ilimiah dan inquiri. Beda halnya dengan model pembelajaran langsung yang merupakan pembelajaran yang berpusat pada guru yang jarang memberi kesempatan kepada siswa untuk menemukan konsep atau fakta dari pengalaman belajar yang dimuat. Berlandaskan teori bahwa keterampilan merupakan keterampilan yang dimiliki oleh orang dalam memilih, menilai dan menemukan sesuatu. Keterampilan proses sains memiliki kaitan yang erat dengan pembelajaran pendekatan saintifik karena pengalaman belajar yang ada mengajarkan seperti apa yang ada pada indikator keterampilan proses sains dasar yaitu mengamati, memprediksi, mengukur, menyimpulkan, dan mengkomunikasi. Faktor itulah yang menjadi dasar sehingga terjadi perbedaan keterampilan proses sains antara siswa yang mengikuti pembelajaran pendekatan saintifik dengan siswa yang mengikuti model pembelajaran konvensional. Hal tersebut terlihat dari pencapaian masing masing indikator keterampilan proses sains dasar untuk pembelajaran pendekatan saintifik, masuk kriteria baik sedangkan untuk model pembelajaran konvensional masuk kriteria cukup baik [6].

Siswa yang diajarkan dengan pembelajaran pendekatan saintifik mengalami peningkatan dalam keterampilan berpikir dan keterampilan proses sains lebih baik apabila dibandingkan dengan model pembelajaran langsung. Dengan demikian maka penelitian ini menunjukkan kesesuaian dan memiliki pengaruh yang positif dalam meningkatkan hasil belajar dan keterampilan proses sains [9]. 
Dalam penelitian ini hasil belajar siswa yang diukur meliputi hasil belajar ranah afektif dan kognitif. Hasil belajar afektif siswa pada kelas eksperimen lebih besar daripada hasil belajar pada kelas kontrol hal tersebut dapat dilihat pada tabel 4.5. Pada pertemuan pertama rerata nilai afektif pada kelas eksperimen adalah 99,46 dan pada pertemuan kedua 99,82 sedangkan pada kelas kontrol pada pertemuan pertama didapatkan rerata 85,92 dan pada pertemuan kedua didapatkan rerata 87,36 . Dari data tersebut dapat diketahui bawa kedua kelas tersebut sama-sama terdapat peningkatan pada pertemuan kedua. Berdasarkan hasil uji-t pada tabel 4.6 menunjukkan bahwa nilai signifikannya $0,000 \quad(<0,05)$. Oleh karena itu, terdapat perbedaan nilai afektif siswa kelas eksperimen dan kelas kontrol.

Hasil Perbandingan selisih rerata pre-test dan post-test dapat diketahui bahwa selisih rerata pre-test dan post-test kelas eksperimen lebih tinggi (41,31) jika dibandingkan selisih rerata pre-test dan post-test kelas kontrol $(31,89)$. Selanjutnya dilanjutkan dengan uji ANAKOVA, berdasarkan hasil uji ANAKOVA pada Tabel 4.8 menunjukkan bahwa nilai signifikannya $0,000<(<0,05)$. Sehingga $\mathrm{H}_{0}$ ditolak, hal ini menunjukkan bahwa pengaruh yang diberikan pada kelas eksperimen (Pendekatan saintifik) dan kelas kontrol (model konvensional) adalah berpengaruh signifikan. Hal ini menunjukkan bahwa antara kelas kontrol dan kelas eksperimen memiliki perbedaan yang nyata. Hal tersebut disebabkan karena siswa pada kelas eksperimen lebih aktif dalam proses pembelajarannya. Siswa kelas eksperimen juga aktif membaca literatur karena mereka dituntut untuk melakukan serangkaian keterampilan proses dasar dan sekaligus mencari jawaban dari apa yang menjadi bahan dalam pembelajaran, sehingga siswa akan mampu memperdalam pengetahuannya secara mandiri. Kegiatan diskusi siswa kelas eksperimen juga aktif, siswa berkolaborasi dalam memecahkan masalah yang ada. Pertanyaan akan timbul dari siswa yang lain dan lainnya akan membantu untuk mencari jawabannya. Keterampilan proses dasar yang dilakukan oleh siswa akan membantu siswa memperdalam pengetahuannya dan mempermudah siswa dalam mengingat materi yang telah mereka terima. Pendekatan saintifik menekankan pada partisipasi aktif siswa dalam proses pembelajaran, dimana siswa memperoleh suatu informasi atau ilmu pengetahuan melalui berbagai pengalaman belajar pokok seperti mengamati, menanya, mengumpulkan informasi, menalar, dan mengomunikasikan.

Dipadukannya pendekatan saintifik dengan teknik mind mapping didalamnya dapat mengembangkan ide kreatif siswa dalam kegiatan pembelajaran sehingga menumbuhkan susasana yang menyenangkan, selain itu minat baca siswa akan bertambah karena sebelum menyampaikan pendapatnya kedepan kelas siswa tersebut harus membaca dan memahami materi yang dibuat pada catatannya. Dengan demikian pemahaman siswa terhadap mataeri yang dibelajarkan akan lebih mendalam yang akan berdampak pula terhadap hasil belajar kognitif dan afektif siswa [7]. Penggunaan pendekatan saintifik membantu siswa untuk meningkatkan keterampilan proses dasar dan meningkatkan kemampuan kognitif dan afektif. Pendekatan saintifik merupakan bagian inti dari kegiatan pembelajaran berbasis kontekstual.
Pengetahuan dan keterampilan yang diperoleh siswa diharapkan bukan hasil mengingat seperangkat fakta tetapi merupakan hasil menemukan sendiri. Konsep-konsep biologi yang ada dan ditemukan sendiri oleh siswa [8].

Dengan demikian tampak bahwa keterampilan proses menjadi dasar dalam memudahkan siswa dalam mengingat dan memahami. Karena siswa terlibat secara langsung dan mandiri dalam memperoleh pengetahuan yang baru. Siswa yang dapat melakukan keterampilan proses adalah siswa yang mampu mengingat dan memahami dengan baik materi yang dipelajarinya. Selanjutnya dikatakan setiap anggota kelompok saling membantu antar sesamanya untuk menguasai materi pelajaran dengan baik. Proses belajar dengan pendekatan saintifik memungkinkan adanya interaksi antar anggota kelompok untuk saling membantu bertukar pendapat sehingga akan dapat meningkatkan penguasaan dan pemahaman konsep yang dipelajari. Pendekatan saintifik dapat meningkatkan pemahaman materi biologi siswa. Dalam pembelajaran ini siswa lebih banyak melakukan serangkaian keterampilan proses secara mandiri untuk mendapatkan informasi. Dengan demikian pemahaman mereka akan materi pelajaran menjadi lebih baik [8].

Peningkatan nilai siswa pada kelas eksperimen diperoleh karena pada kelas ini dilakukan perlakuan dengan pendekatan saintifik dengan teknik mind mapping sehingga membuat siswa lebih aktif dalam mengikuti proses pembelajaran. Pendekatan saintifik akan dapat menumbuhkan pembelajaran yang efektif yaitu pembelajaran yang/bercirikan memberi kesempatan kepada siswa untuk belajar secara langsung dan mandiri.

\section{Kesimpulan dan Saran}

Berdasarkan pada uraian hasil penelitian dan analisis data yang telah dilakukan maka dapat disimpulkan bahwa penerapan pendekatan saintifik dengan teknik mind mapping berpengaruh terhadap keterampilan proses dasar dan hasil belajar siswa secara signifikan dengan nilai probabilitas $(\mathrm{p})$ $<-0,05$. Perlu dilakukan penelitian lebih lanjut tentang pendekatan saintifik dengan teknik pembelajaran yang lain pada topik yang berbeda.

\section{Ucapan Terima Kasih}

Ucapan terimakasih disampaikan kepada kepala SMA N 2 Tanggul yang telah memberikan izin untuk melakukan penelitian dan Nur Akhmad, S.Pd selaku guru mata pelajaran Biologi yang telah membantu dalam melaksanakan penelitian ini. Penulis juga mengucapkan terima kasih kepada teman-teman yang telah membantu dalam melakukan observasi.

\section{Daftar Pustaka}

[1] Baswedan, Anies. 2015. Rencana Strategis Kementerian Pendidikan dan Kebudayaan 2015-2019. Jakarta: Kementerian Pendidikan dan Kebudayaan.

[2] Hosnan, M. 2013. Pendekatan Saintifik dan Kontekstual dalam Pembelajaran Abad 21kunci suskes implementsi kurikulum 2013. Jakarta:Ghalia Indonesia. 
[3] Kemendikbud. 2014. Peraturan Menteri Pendidikan dan Kebudayaan RI Tentang Implementasi Kurikulum Pedoman Umum Pembelajaran. Jakarta: Kemendikbud.

[4] Putranto, Tinto. 2010. Penggunaan Strategi Pembelajaran Mind Map untuk meningkatkan Hasil Belajar Biologi Pada Pokok Bahasan Sistem Peredaran Darah Manusia Siswa Kelas XI IPA SMA Muhammadiyah 2 Surakarta Tahun Ajaran 2010. Surakarta: Universitas Muhammadiyah Surakarta.

[5] Herdian. 2009. Model Pembelajaran Mind Mapping. Http://herdy07.wordpress.com/2009/04/29/model-pembelajaran-mind mapping[19 Desember 2015].

[6] Majid, A. 2014. Pembelajaran Tematik Terpadu.Bandung: Remaja Rosda Karya.

[7] Mardikayasa, I.M, Komang Ngurah, Asri,Sri. 2015. Penerapan Mind Mapping dalam Pendekatan Saintifik untuk Meningkatkan Hasil Belajar PKn dan Sikap Sosial Tema Cita-Citaku pada Siswa Kelas IVA SD Negeri 29 Pemecutan. E-Journal. Vol. 3 No.1.

[8] Irwandi. 2012. Pengaruh Pendekatan Kontekstual dalam Pembelajaran Biologi melalui Strategi Inkuiri dan Masyarakat Belajar pada Siswa dengan Kemampuan Awal Berbeda terhadap Hasil Belajar kognitif di SMA Negeri Kota Bengkulu. Jurnal Kependidikan Triadik, 12(1): 33-41.

[9] Marjan, Johari. 2014. Pengaruh Pembelajaran Pendekatan Saintifik terhadap Hasil Belajar Biologi dan Keterampilan Proses Sains Siswa MA Mu'allimat NW Pancor Selong Kabupaten Lombok Timur Nusa Tenggara Barat. E-journal. Vol.4. Universitas Pendidikan Ganesha Singaraja Indonesia.

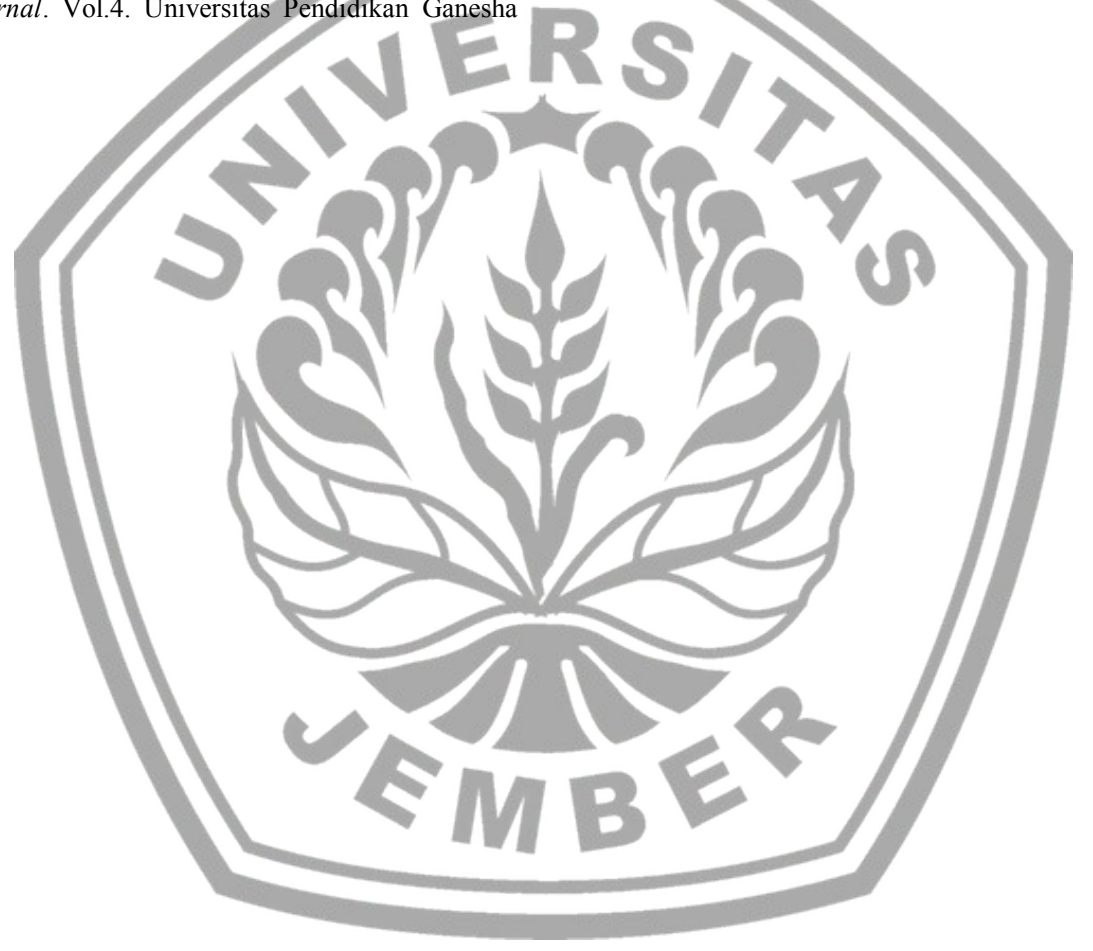

